\title{
Antioxidant Properties of Plant Extracts: an EPR and DFT Comparative Study of the Reaction with DPPH, TEMPOL and Spin Trap DMPO
}

\section{Adevailton Bernardo dos Santos, ${ }^{*, a, d}$ Dulce Helena Siqueira Silva, ${ }^{b}$ Vanderlan da Silva Bolzani, ${ }^{b}$ Luciana Ávila Santos, ${ }^{b}$ Tomé Mauro Schmidt ${ }^{c}$ and Oswaldo Baffa ${ }^{d}$}

${ }^{a}$ Faculdade de Ciências Integradas do Pontal, Universidade Federal de Uberlândia, 38302-000 Ituiutaba-MG, Brazil

${ }^{b}$ Instituto de Química, Universidade Estadual Paulista, 14800-900 Araraquara-SP, Brazil

'Instituto de Física, Universidade Federal de Uberlândia, CP 593, 38400-902 Uberlândia-MG, Brazil

${ }^{d}$ Departamento de Física e Matemática, Faculdade de Filosofia Ciências e Letras de Ribeirão Preto, Universidade de São Paulo, 14040-901 Ribeirão Preto-SP, Brazil

\begin{abstract}
Este trabalho apresenta um estudo comparativo da atividade antioxidante dos extratos de nove espécies de plantas pertencentes à flora brasileira - Swartzia langsdorffi, Machaerium villosum, Pterogyne nitens, Pera glabrata, Aegiphyla sellowiana, Copaifera langsdorffi, Chrysophyllum inornatum, Iryanthera juruensis, Didymopanax venosum - neutralizando os radicais livres DPPH (2,2-difenil-1-picrilhidrazil) e TEMPOL (4-hidróxi-2,2,6,6-tetrametil-1-piperidiniloxi-1-oxil) utilizando ressonância paramagnética eletrônica (RPE), e agindo sobre os radicais hidroxila $(\mathrm{OH} \bullet)$ gerados por uma reação Fenton, através da técnica de spin-trapping. Os melhores resultados foram obtidos para os extratos de Iryanthera juruensis e Chrysophyllum inornatum. Os resultados dos testes foram acompanhados por cálculos computacionais dos compostos, utilizando a teoria do funcional da densidade (TFD), com aproximação local da densidade (ALD), e o código SIESTA. Os resultados indicaram que a energia liberada na reação de redução TEMPOL é inferior a DPPH. Como o DPPH é um composto de menor custo e mais disponível tem um uso mais amplo que o TEMPOL, entretanto este último deve ser considerado quando se quer estudar processos que envolvam menores energias.
\end{abstract}

This work presents a comparative study of the antioxidant activity of extracts from nine plant species belonging to the Brazilian flora - Swartzia langsdorffi, Machaerium villosum, Pterogyne nitens, Pera glabrata, Aegiphyla sellowiana, Copaifera langsdorffi, Chrysophyllum inornatum, Iryanthera juruensis, Didymopanax venosum - acting on the free-radicals DPPH (2,2-diphenyl1-picrylhydrazyl) and TEMPOL (4-hydroxy-2,2,6,6-tetramethyl-1-piperidinyloxy-1-oxyl) by electron paramagnetic resonance (EPR), and acting on the hydroxyl radical $(\mathrm{OH} \bullet)$ by the spintrapping technique generated by a Fenton reaction. Results showed that the extracts of Iryanthera juruensis and Chrysophyllum inornatum display the strongest antioxidant activities. The results of scavenging tests were clarified by computational calculations - density functional theory (DFT), local density approximation (LDA) with SIESTA code - indicating that the energy released in the reduction reaction of TEMPOL is less than DPPH. Due to its availability and cost DPPH is more often used in these tests than TEMPOL, however TEMPOL should be considered when studying processes dealing with smaller energies.

Keywords: EPR, TEMPOL, DPPH, DMPO, DFT

\section{Introduction}

Upon normal metabolic reaction, which includes several oxidative steps, lipids, sugars and proteins can generate aldehydes, ketones, esters and other products possessing

*e-mail: adevailton@pontal.ufu.br chemical and biological properties which may be harmful to living systems. Dietary antioxidants can prevent the oxidation of such compounds by assisting in the elimination of free radicals generated by the metabolism, mainly reactive oxygen species (ROS). ${ }^{1}$ At the present there is a great interest in studies with antioxidants compounds and they are gaining importance, mainly from natural sources: plants used in 
everyday diet and plants that have phytotherapeutic use such as teas beverages. Usually stable free radicals and spin traps are used in these studies to identify the reactants and to measure reaction rates. ${ }^{2-6}$

This work used electron paramagnetic resonance (EPR), a spectroscopic technique for selective detection of free radicals. EPR has wide use such as fossils dating, identification of paramagnetic substances, ionizing radiation dosimeters and other applications, ${ }^{7-8}$ including antioxidant evaluation, allowing studies on the kinetics and stoichiometry of the reactions of radicals and antioxidant compounds. One way to perform these measurements is by measuring the concentration of free radicals that are in contact with the antioxidant substance by using stable free radicals as DPPH and TEMPOL (Scheme 1). DPPH and TEMPOL are known as standard substances in EPR spectroscopy ${ }^{9,10}$ and are largely applied in studies of the antioxidant activity. DPPH is one of the molecules frequently used for measuring antioxidant activities, in optical spectroscopy measurements as well as in EPR. ${ }^{1-}$ 3,6,11,12 TEMPOL is less used for this purpose $\mathrm{e}^{4,13-15}$ once in contact with other free radicals it can show antioxidant activity, either in its original form or in reduced form TEMPOL-H. ${ }^{16}$

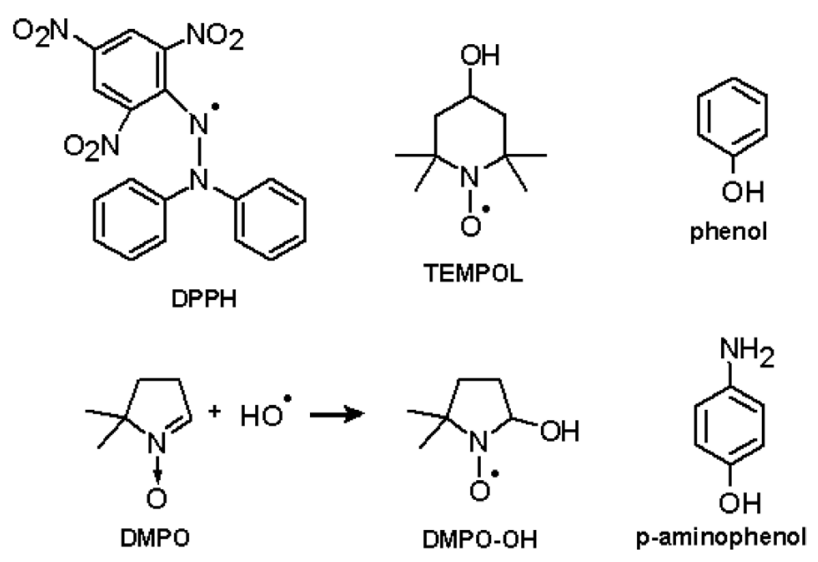

Scheme 1. Structural formula of free radicals DPPH and TEMPOL; $\mathrm{DMPO}$ and respective spin adduct DMPO-OH; phenol and $p$-aminophenol.

Another approach to carry out studies of antioxidant substances is to use the spin-trapping technique, consisting in generating free radicals, which normally have a short lifetime, and placing them in contact with a spin trap. The result of this reaction is the generation of a spin adduct that has a longer lifetime ${ }^{2,6,17,18}$ allowing its monitoring by EPR spectroscopy or other technique. So, for the study of the antioxidant activity of a compound against the hydroxyl radical $(\mathrm{OH} \bullet)$, this technique can be used: the Fenton reaction $\left(\mathrm{Fe}^{2+}+\mathrm{H}_{2} \mathrm{O}_{2} \rightarrow \mathrm{Fe}^{3+}+\mathrm{OH} \bullet+\mathrm{HO}^{-}\right)$generates the hydroxyl radical, and the spin trap DMPO (5,5-dimethyl- 1-pyrroline $\mathrm{N}$-oxide) traps it, leading to the formation of the spin adduct DMPO-OH (Scheme 1).

One goal in this study was to carry out a comparative analysis of the antioxidant activity of some species of the Brazilian flora. The species compared in this work are: Swartzia langsdorffi, Machaerium villosum, Pterogyne nitens, Pera glabrata, Aegiphyla sellowiana, Copaifera langsdorffii, Chrysophyllum inornatum, Iryanthera juruensis, Didymopanax venosum which have been selected due to the presence of antioxidant compounds in their ethanol extracts, evidenced by preliminary screening in a TLC test using beta-carotene solution as revealing agent. Despite the possibility of studies using extracts prepared in other solvents, this work uses only ethanol extracts for initial tests. These results could serve as a reference for future work with fractions of these extracts.

The other objective of this work is to get information on the molecular structures, energies and some electronic properties of free radicals DPPH and TEMPOL, and of spin-trap DMPO, in gas-phase, using the density functional theory (DFT) calculations, with local density approximation $(\mathrm{LDA})^{19}$ and use of pseudopotentials. Despite several works with antioxidants compounds, little attention is given to the free radicals used in tests, however the knowledge on the properties of these free radicals can help to analyze the results. The results of computational calculations aided to elucidate the differences between results of antioxidant activities from the same extract, mainly that DPPH react differently than TEMPOL. The main focus of these calculations is to determine hydrogen bond dissociation energy (BDE) to estimate the energies involved in the reactions of the free radicals studied with antioxidants compounds.

The reaction with antioxidant compounds (A) and free radicals (Fr) can occur through different pathways: Hydrogen atom transfer (HAT) (reaction I) or a process involving electron transfer (ET) and proton transfer (PT). One of the processes involving ET and PT is sequential proton loss electron transfer (SPLET) (reaction II) where hydrogen bond acceptor (HBA) solvent (S) reacts by ionizing antioxidant compound for proton loss followed by electron transfer from antioxidant compound to free radical. Another process is proton coupled electron transfer (PCET) in which electron and proton transfer occurs simultaneously, similar to HAT (reaction I) but in different molecular orbital: the proton is then transferred from two bonding electron antioxidant compound to the radical's lone pair while electron move from $2 p$ lone pair antioxidant compound to the radical's single occupied molecular orbital (SOMO). There is another case where first occurs electron transfer followed by proton transfer (ETPT) (reation III), with the proton reacting with the $\mathrm{Fr}^{-}$or with solvent, if it is good HBA. ${ }^{20}$ 
$\mathrm{Fr} \bullet+\mathrm{A}-\mathrm{OH} \rightarrow \mathrm{Fr}-\mathrm{H}+\mathrm{A}-\mathrm{O} \bullet$

$\mathrm{Fr} \bullet+\mathrm{A}-\mathrm{OH}--\mathrm{S} \rightarrow \mathrm{Fr} \bullet+\mathrm{A}_{-} \mathrm{O}^{-}+\mathrm{HS}^{+} \rightarrow \mathrm{Fr}^{-}+\mathrm{A}-\mathrm{O} \bullet+\mathrm{HS}^{+}$(II)

$\mathrm{Fr} \bullet+\mathrm{A}-\mathrm{OH} \rightarrow \mathrm{Fr}^{-}+\mathrm{A}-\mathrm{OH}^{+} \rightarrow \mathrm{A}-\mathrm{O} \bullet+\mathrm{H}^{+}+\mathrm{Fr}^{-}$

Independent of the preferential reaction route followed, our calculations are focused in HAT process and the results serve for estimation of the released energy in the reduction of free radical by antioxidant compound. Thus, the main goal of the this work is to compare the anti oxidative properties of several natural extracts against DPPH, TEMPOL and the spin trapping DMPO and to give some explanation of our findings based on the density functional theory (DFT).

\section{Experimental}

\section{Reagents and plants materials}

DPPH, TEMPOL, DMPO and quercetin were purchased from Sigma-Aldrich Chemical Co and used without further purification; ethanol (>99.9\%) and hydrogen peroxide (30\%) $\left(\mathrm{H}_{2} \mathrm{O}_{2}\right)$ from Labsynth LTDA-Brazil; and ferrous sulphate $\left(\mathrm{FeSO}_{4}\right)$ from Vetec LTDA-Brazil. Plant materials were collected in Mogi Guaçu State Park (Cerrado), Jureia-Itatins State Park (Atlantic Forest), Mocambo Reserve (Amazon Forest) and identified by botanists Inês Cordeiro and Nelson Rosa. Voucher specimens were deposited at Museu Paraense Emílio Goeldi, PA, and Herbarium of Instituto de BotânicaSEMA, SP.

\section{EPR spectrometer and data analyses}

A Varian E-4 X-band spectrometer computer interfaced allowing signal averaging and fast measurements equipped with a rectangular cavity (TE-102, model E-231) was used for the EPR measurements. Operation parameters were as follows: microwave power $10 \mathrm{~mW}$, center magnetic field $338 \mathrm{mT}$, sweep width $10 \mathrm{mT}$, modulation frequency $100 \mathrm{kHz}$, modulation amplitude $0.1 \mathrm{mT}$ and room temperature $24 \pm 2{ }^{\circ} \mathrm{C}$. The data and graphical analyses were carried out using the Microcal Origin 7 software.

\section{Plants extracts}

Seeds and leaves of Iryanthera juruensis (50 g, each) as well as leaves of Swartzia langsdorffi, Machaerium villosum, Pterogyne nitens, Pera glabrata, Aegiphila sellowiana, Copaifera langsdorffii, Chrysophyllum inornatum, Didymopanax venosum (50 g, each) were dried, ground and submitted to extraction with ethanol (cold, $3 x$ ). Each ethanol solution was evaporated under reduced pressure, affording the ethanol extracts used in this study.

\section{DPPH scavenging test}

The antioxidant activities of the plant extracts against the free radical present in DPPH were studied using ethanol solutions of the extracts at several concentrations. Aliquots of DPPH solution in ethanol $\left(1 \mathrm{mmol} \mathrm{L} \mathrm{L}^{-1}, 40 \mu \mathrm{L}\right)$ and each extract solution $(40 \mu \mathrm{L})$ were mixed, stirred for $10 \mathrm{~s}$ and then transferred to a capillary tube. The capillary tube was sealed and placed inside a standard EPR quartz tube (inner diameter $3.00 \mathrm{~mm}$ ), which was placed in the resonant cavity. This procedure took $3 \mathrm{~min}$ and it was carried out at room temperature. For the reference measurement the extract solution was replaced by ethanol $(40 \mu \mathrm{L})$. Data were reported as the average of three measurements. The procedure was repeated with quercetin.

Spectra simulation was carried out by the computer program Winsim, and the double integral of the signal was evaluated as representative of the free radical concentration. Results were plotted in a graph of the double integral intensity versus extract concentration. By graphical analysis, it was possible to determine the concentration that reduces the initial signal intensity by $50 \%$ (IC 50). The spectra are a result of 3 scans average with 30 s scan time.

\section{Hydroxyl radical scavenging test}

Extracts solutions were prepared in deionized water, at different concentrations. $\mathrm{H}_{2} \mathrm{O}_{2}\left(20 \mu \mathrm{L}, 100 \mathrm{mmol} \mathrm{L}^{-1}\right)$, $\mathrm{FeSO}_{4}\left(20 \mu \mathrm{L}, 10 \mathrm{mmol} \mathrm{L}^{-1}\right)$, DMPO $\left(20 \mu \mathrm{L}, 50 \mathrm{mmol} \mathrm{L}^{-1}\right)$, and extract solution $(20 \mu \mathrm{L})$ in phosphate buffer solution were mixed. The resulting solution was stirred for $10 \mathrm{~s}$ and transferred to a capillary tube, and placed in the EPR cavity as mentioned before. This procedure took $3 \mathrm{~min}$. For the measurement of a reference signal the extract solution was replaced by $20 \mu \mathrm{L}$ deionized water. Spectra of the spin adduct DMPO-OH were recorded with 1 scan of $30 \mathrm{~s}$. Data are the mean values of three measurements. Results were calculated as the sum of the intensity of the four hyperfine EPR lines of the spectra, and they are then plotted in a graph of the signal intensity versus extract concentration. By graphical analysis it was possible to determine the concentration that reduces the initial signal intensity by $50 \%$ (IC 50).

\section{TEMPOL scavenging test}

Extracts solutions were prepared in both ethanol and deionized water $\left(20 \mathrm{mg} \mathrm{mL}^{-1}\right)$. Each extract solution $(40 \mu \mathrm{L})$ was mixed with TEMPOL solution in deionized water $\left(10 \mu \mathrm{mol} \mathrm{L} \mathrm{L}^{-1}, 40 \mu \mathrm{L}\right)$. The resulting solution was stirred for $10 \mathrm{~s}$ and transferred to a capillary tube. The rest of the procedure was as above, with the exception of 
time measurement, now repeated at 1,2 and $24 \mathrm{~h}$ intervals. Spectra were averaged after 5 scans with $60 \mathrm{~s}$ scan time. In the reference, the extract solution was substituted for $40 \mu \mathrm{L}$ of ethanol or deionized water. Finally, the procedure was carried out with quercetin in ethanol and water solution $\left(2 \mathrm{mg} \mathrm{mL}^{-1}\right)$ mixtures with TEMPOL in water $\left(10 \mu \mathrm{mol} \mathrm{L}^{-1}\right)$, for comparative test.

The extract of Chrysophyllum inornatum, showing good results for antioxidant activities, was tested for higher TEMPOL concentrations and longer time intervals. The comparative study with the extract in water solution and ethanol solution was performed. Mixtures of $40 \mu \mathrm{L}$ of the solution of TEMPOL in water $\left(0.10 \mathrm{mmol} \mathrm{L}^{-1}\right)$ and $40 \mu \mathrm{L}$ of the extract solution in ethanol $\left(20 \mathrm{mg} \mathrm{mL}^{-1}\right)$ or $40 \mu \mathrm{L}$ of the extract solution in deionized water $\left(20 \mathrm{mg} \mathrm{mL}^{-1}\right)$. In the reference solution the extract solution was substituted for $40 \mu \mathrm{L}$ of ethanol or water.

The results presented herein were obtained after adding up the amplitude of the 3 hyperfine lines of the spectra, from which the percentage of TEMPOL neutralization was calculated. This measurement is expressed by equation 1 :

$\mathrm{P}=($ ref-ext $) /($ ref-bg $)$

where $\mathrm{P}$ is the percentage of decrease in the signal intensity, ref is the intensity of the reference signal, ext is the intensity of the signal due to the mixture of the free radical with the extract solution and bg is the background signal.

\section{Computational calculations}

The molecules of DPPH, TEMPOL and DMPO were simulated in gas-phase. DFT-LDA with use of pseudopotentials provides the theoretical framework of our calculations. The pseudopotentials are generated using the norm of Troullier-Martins. ${ }^{21}$ The computational code used is SIESTA. ${ }^{22}$ The exchange-correlation functional used the results of Ceperley and Alder ${ }^{23}$ as parametrized by Perdew and Zunger. ${ }^{24} \mathrm{~A}$ double-zeta added polarized functions (DZP) basis set was employed, and a mesh cutoff of 140 Ry was used for the reciprocal-space expansion of the charge density. All the geometries were optimized until the remaining forces were lower than $0.01 \mathrm{eV} / \AA$. The Brillouin zone was sampled by four $\mathrm{k}$ points.

\section{Results and Discussions}

\section{DPPH scavenging test}

The IC 50 results is presented in Table 1 . The most efficient extract for DPPH scavenging was that from Iryanthera juruensis (leaf and seed) extracts. These extracts displayed high antioxidant activity when compared to the one obtained for Filipendula ulmaria, a native plant of France, in a similar experiment. ${ }^{3}$ The IC 50 values obtained for the leaves extract $\left(0.028 \mathrm{mg} \mathrm{mL}^{-1}\right)$ and seeds extract $\left(0.041 \mathrm{mg} \mathrm{mL}^{-1}\right)$ of Iryanthera juruensis, when compared to quercetin $\left(0.017 \mathrm{mg} \mathrm{mL}^{-1}\right)$ indicated a great concentration of antioxidant compounds. Copaifera langsdorffi, Chrysophyllum inornatum and Pterogyne nitens have also shown low IC 50 values, indicating high antioxidant capacity. Previous phytochemical work on these species evidenced the presence of flavonoids in their leaves extracts, which may have contributed to the overall high activity. ${ }^{25-27}$

The higher IC 50 value was obtained for the extract from Swartzia langsdorffii, indicating that this plant has moderate antioxidant activity. It has been reported that its extract contains isoflavonoids, which might be responsible for the observed activity. ${ }^{28-30}$

The DPPH test is easy to perform, reliable and reproducible, for this reason has been widely used in the analysis of antioxidant activities, both in EPR spectroscopy and in the bleaching technique, which measures the optical absorption intensity at 515-517 $\mathrm{nm}$. The fact that the DPPH EPR spectrum has a relatively simple signal due only to the free radical is an advantage in relation to the optical spectroscopy. In the latter, besides the appearance of absorptions due to the presence of other compounds in the extract, there is also an increment at $320 \mathrm{~nm}$, corresponding

Table 1. Antioxidant activity of plant extracts against the radicals DPPH and DMPO-OH, results indicated for IC 50 (mg $\left.\mathrm{mL}^{-1}\right)$

\begin{tabular}{|c|c|c|c|c|c|c|c|c|c|c|c|}
\hline & 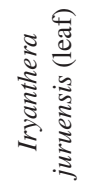 & 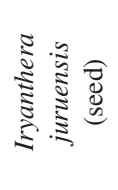 & 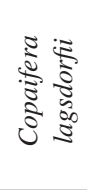 & 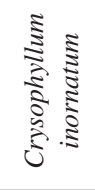 & 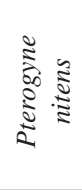 & $\frac{\sqrt{\pi}}{\sqrt[3]{\pi}}$ & 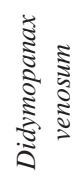 & $\begin{array}{c}\sqrt{2} \\
0 \\
0 \\
0 \\
0 \\
0 \\
0 \\
0 \\
0\end{array}$ & 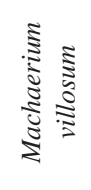 & 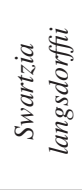 & 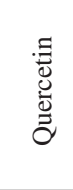 \\
\hline $\begin{array}{l}\text { DPPH scavenging } \\
\text { IC50 }\left(\mathrm{mg} \mathrm{mL}^{-1}\right)\end{array}$ & 0.028 & 0.041 & 0.057 & 0.077 & 0.159 & 0.269 & 0.375 & 0.452 & 0.717 & 1.532 & 0.017 \\
\hline $\begin{array}{l}\text { Hydroxyl scavenging } \\
\text { IC50 }\left(\mathrm{mg} \mathrm{mL}^{-1}\right)\end{array}$ & 1.676 & 1.252 & 1.772 & 13.945 & 2.063 & 3.299 & 9.567 & 9.022 & 10.720 & 5.408 & \\
\hline
\end{tabular}


to the increase in DPPH-H concentration due to DPPH reduction to the respective hydrazine. ${ }^{9}$

Despite the advantage of using EPR technique for DPPH scavenging test, this result indicates only the antioxidant activity and not the mechanism of its reduction reaction. The tests were carried out in ethanol solution, polar and HBA solvent, and in this form the reaction of DPPH reduction occurs by a combination of the classical HAT mechanism and a process involving PT and ET, mainly SPLET with ionization of antioxidant compound. ${ }^{20}$ In this case the SPLET mechanism was favored in solvents having high dielectric constant and ability to solvate anions increasing its stability similar to ethanol.

\section{Hydroxyl radical scavenging test}

Results concerning IC 50 for the hydroxyl radical scavenging test are presented in Table 1, and the small differences are in agreement with results obtained in the other tests. As observed in DPPH test, the Iryanthera juruensis (leaf and seed) extracts showed the strongest antioxidant activity. The low activity of Chrysophyllum inornatum extract contrasts with results from the other tests, in which this extract showed a strong activity.

The spin trap technique with Fenton reaction for hydroxyl scavenging test, similar to that employed in this work is very common, ${ }^{3,6,17,30}$ but some comments have to be made. The EPR signal is proportional to the concentration of spin adduct in the solution after a certain time of reaction, but the form of inhibition of this signal is not indicated. It could be due to: (a) donation of a proton or electron to the radical spin adduct; (b) competition between the antioxidant species and the spin trap for the hydroxyl radical; (c) suppression of hydroxyl radical formation by reaction of the spin trap or the extract with compounds involved in the Fenton reaction $\left(\mathrm{H}_{2} \mathrm{O}_{2}\right.$ or $\left.\mathrm{Fe}^{2+}\right){ }^{6,31}$

Despite the problems in determining the reaction pathway, it is clear that in all the three forms above mentioned it is possible to measure antioxidant activity, either in relation to the radical hydroxyl or for the capacity of the extract to chelate metals. Our results are in agreement with those from previous works on plant extracts and polyphenols. ${ }^{3,6,32}$

\section{TEMPOL scavenging test}

Despite the little use of TEMPOL scavenging test, the implementation of TEMPOL aqueous solution makes the environment more similar to that encountered in living organisms, in contrast with DPPH, which is used more frequently in ethanol solution. We used $20 \mathrm{mg} \mathrm{mL}^{-1}$ of extract for $10 \mu \mathrm{mol} \mathrm{L}{ }^{-1}$ of TEMPOL. Despite of variations, normally the TEMPOL reacts in different pathway, for the same antioxidant compound, when compared with DPPH, and has the capacity of reacting with free radicals in organisms, showing antioxidant activity, ${ }^{4}$ however, its application in EPR spectroscopy, monitoring antioxidant activities, mainly in hydrosoluble systems, is of great importance, complementing the result of the DPPH scavenging test. Kinetic data obtained from reaction of TEMPOL with TROLOX (in excess TROLOX) indicated single exponential decay of TEMPOL concentration with rate constant $5.04 \mathrm{~h}^{-1}$, and conclusions indicated that reaction occurs mainly via HAT due to little dependence on the rate constant with $\mathrm{pH}$ variations. ${ }^{14}$ The reaction of TEMPOL with antioxidant compounds has a second-order behavior, however in lower concentrations of nitroxide, kinetics were pseudo-first-order with respect to the nitroxide. ${ }^{15}$

TEMPOL scavenging test using extracts in ethanol solution

The percentage of TEMPOL neutralization, by the plant extracts and as a function of time is presented in Table 2. The most efficient extract for TEMPOL neutralization was that from Chrysophyllum inornatum. In this case, the TEMPOL concentration decreases from $5.0 \mu \mathrm{mol} \mathrm{L}^{-1}$ to a value lower than $0.30 \mu \mathrm{mol} \mathrm{L}^{-1}$ in about $2 \mathrm{~h}$, which is the minimum concentration that our EPR spectrometer can detect in the present experiment.

The extracts from Machaerium villosum, Pterogyne nitens, Pera glabrata, Iryantera juruensis (leaf), and Copaifera langsdorffii showed similar results, with neutralization of TEMPOL $c a$. $70 \%$. The extracts of Iryantera juruensis (leaf and seed), showed moderate activity in this test although higher activities were observed for these extracts in the DPPH test.

By analyzing the TEMPOL concentration after its contact with the extract from Swartzia langsdorffii, at the beginning an increase in percentage of this radical reduction was observed, followed by a small decrease between $1 \mathrm{~h}$ and $2 \mathrm{~h}$. It has been described that TEMPOL can be reduced to a hydroxylamine, and this substance is able to re-oxidize to the paramagnetic nitroxide again. ${ }^{13}$ This might explain the variation of TEMPOL concentration in this case. Similar results were obtained with Didymopanax venosum extract.

TEMPOL scavenging test using extracts in water solution

The percentage of TEMPOL neutralization by the plant extracts as a function of time is presented in Table 2. Again, the most efficient extract is the one obtained from Chrysophyllum inornatum. The higher difference occurs in 
Table 2. Percentage of TEMPOL neutralization by the plant extracts as a function of time and solvent

\begin{tabular}{|c|c|c|c|c|c|c|c|c|c|c|c|c|}
\hline & & 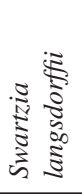 & 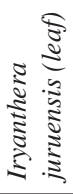 & 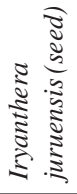 & 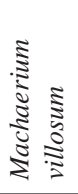 & $\begin{array}{c}\frac{5}{0} \\
\frac{0}{0} \\
\frac{0}{0} \\
0 \\
0 \\
0 \\
0\end{array}$ & 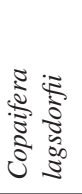 & 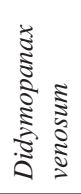 & 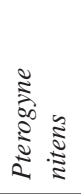 & 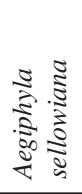 & 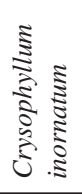 & 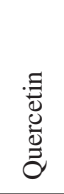 \\
\hline \multirow{4}{*}{$\begin{array}{l}\text { Extracts } \\
\text { water } \\
\text { solution }\end{array}$} & $0 \mathrm{~h}$ & 3.5 & 9.3 & 7.7 & 3.7 & 15.1 & 11.3 & 4.5 & 3.9 & 8.6 & 4.0 & 1.0 \\
\hline & $1 \mathrm{~h}$ & 5.0 & 33.6 & 34.1 & 16.0 & 36.8 & 34.8 & 28.5 & 27.5 & 22.1 & 42.1 & 5.1 \\
\hline & $2 \mathrm{~h}$ & 5.9 & 40.2 & 48.5 & 29.7 & 38.2 & 45.7 & 38.3 & 42.1 & 46.5 & 56.5 & 11.6 \\
\hline & $24 \mathrm{~h}$ & 3.5 & 78.0 & 81.3 & 82.8 & 83.0 & 86.2 & 100.0 & 100.0 & 100.0 & 100.0 & 48.9 \\
\hline \multirow{4}{*}{$\begin{array}{l}\text { Extracts } \\
\text { ethanol } \\
\text { solution }\end{array}$} & $0 \mathrm{~h}$ & 20.0 & 12.7 & 13.9 & 20.9 & 8.2 & 8.4 & 17.2 & 17.3 & 4.8 & 24.9 & 1.1 \\
\hline & $1 \mathrm{~h}$ & 22.2 & 43.7 & 30.6 & 32.7 & 29.8 & 45.7 & 15.6 & 43.9 & 16.5 & 71.2 & 6.3 \\
\hline & $2 \mathrm{~h}$ & 20.8 & 49.6 & 40.5 & 53.4 & 33.2 & 48.7 & 27.9 & 53.3 & 20.6 & 100.0 & 17.4 \\
\hline & $24 \mathrm{~h}$ & 25.9 & 74.8 & 45.4 & 63.9 & 73.4 & 78.9 & 54.9 & 69.1 & 21.9 & 100.0 & 51.0 \\
\hline
\end{tabular}

Aegiphyla sellowiana and Didymopanax venosum extracts: in ethanol solution, the antioxidant activity was not good, but in water solution, a decrease in TEMPOL concentration lower than the detection limit was observed.

The antioxidant activity of extracts in water solution is similar to extracts in ethanol solution, but it is worth noting that in water solution the kinetic is different. The initial activity, in the first hour, is lower for seven extracts and after $24 \mathrm{~h}$ higher for eight extracts. Comparing with extracts dissolved in water, in general, when extracts are dissolved in ethanol, the antioxidant activity against TEMPOL is higher at first hour, but for longer times the speed of reaction decreases, and after $24 \mathrm{~h}$, the antioxidant activity is lower. This result indicates that the solvent is important for TEMPOL scavenging test. Despite the small difference, the best antioxidant performance of these extracts was obtained in water solutions.

The results of test with larger TEMPOL concentrations and longer time intervals, using Chrysophyllum inornatum extracts after $40 \mathrm{~h}$ of analysis is presented in Figure 1, with the EPR signal intensity as a function of time. The decrease of EPR signal intensity can be fitted to a biexponential decay, with one fast component and another slow one (equation 2). Considering that in lower concentration of TEMPOL its reduction occurs with pseudo-first-order kinetic and this result depends on composition of each individual extract, this result is compatible with the action of more than one antioxidant substance with different kinetic rates, and compatible with a non purified extract.

$$
\operatorname{EPR}(\text { signal })=\mathrm{Ae}^{-\mathrm{k}_{\mathrm{A}} \mathrm{t}}+\mathrm{Be}^{-\mathrm{k}_{\mathrm{B}} \mathrm{t}}
$$

Analyzing the decay rate constants (equation 2), the following values were obtained in ethanol $\mathrm{k}_{\mathrm{A}}=0.694 \mathrm{~h}^{-1}$ and $\mathrm{k}_{\mathrm{B}}=0.097 \mathrm{~h}^{-1}$ and in water $\mathrm{k}_{\mathrm{A}}=1.316 \mathrm{~h}^{-1}$ and $\mathrm{k}_{\mathrm{B}}=0.093 \mathrm{~h}^{-1}$.
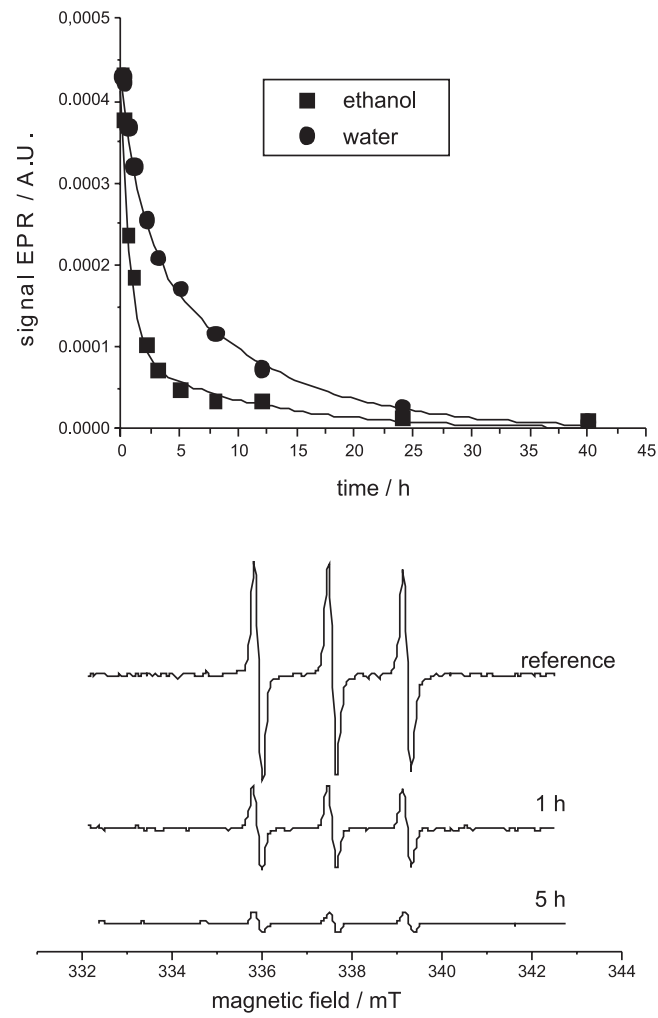

Figure 1. Above, the TEMPOL EPR signal decay, in the presence of Crysophyllum inornatum extract solubilized in water and ethanol; and its respective fit biexponential decay. Below, EPR spectra of TEMPOL with Crysophyllum inornatum extracts after $1 \mathrm{~h}, 5 \mathrm{~h}$ and reference.

The main difference occurs when we compare the initial amplitude ratios: in ethanol $\mathrm{A} / \mathrm{B}=3.61$ and water $\mathrm{A} / \mathrm{B}=0.68$. These values are close to the ones reported by Polovka et al. ${ }^{4}$ working with tea beverages: the formal first-order rate constants varying from $0.052 \mathrm{~h}^{-1}$ to $1.77 \mathrm{~h}^{-1}$, depending on the tea sample analyzed.

It seems that in ethanol the fast component is more effective while in water it is the opposite. It can be seen 
that the constant $\mathrm{A}$ is proportional to the concentration of antioxidant compounds that react with higher decay rate constant $\left(\mathrm{k}_{\mathrm{A}}\right)$, while the constant $\mathrm{B}$ is proportional to the concentration of antioxidant compounds that react with lower decay rate constant $\left(\mathrm{k}_{\mathrm{B}}\right)$. The result of the $\mathrm{A} / \mathrm{B}$ ratio may suggest that in ethanol solution some antioxidant compounds react more quickly than in water solution, confirming the fact that the antioxidant activity of extracts in ethanol is faster for saturation, despite the little difference in larger time intervals.

Finally, the study with quercetin indicated that this flavonoid exhibits moderate antioxidant activity towards TEMPOL, as shown in Table 2, evidencing that after $24 \mathrm{~h}$ about $50 \%$ of TEMPOL radical was reduced, and the reaction was faster in ethanol solution.

There is a consensus over the importance of the solvent in antioxidant reactions, mainly with phenolic compounds. The antioxidant activity is higher in non-polar organic solvents and decreases when solvent HBA (hydrogen bond acceptor) increases. ${ }^{33-34}$ Considering that water is the best HBA solvent and more polar than ethanol, these results agree with the expected. In addition, the low solubility of flavonoids in water contributes to explaining the lower antioxidant activity of quercetin when compared to Chrysophyllum inornatum extract; and also the slightly higher activity of quercetin in ethanol than in water solution.

The higher reactivity of DPPH with solution of plant extracts may be due to the energy released in its reaction of reduction being higher than compared to the TEMPOL, and justifies its broader use. On the other hand, after $24 \mathrm{~h}$ TEMPOL scavenging test does not show significant differences while being used with solution extracts in water and ethanol.

\section{Computational calculations}

The calculation of bond dissociation energy (BDE) for phenol or $p$-aminophenol (A) was made through the reaction $\mathrm{A}-\mathrm{OH} \rightarrow \mathrm{A}-\mathrm{O} \bullet+\mathrm{H} \bullet$, and the calculation of variation $\mathrm{BDE}$ of $p$-aminophenol in relation phenol from $\Delta \mathrm{BDE}=\mathrm{BDE}(p$-aminophenol $)-\mathrm{BDE}($ phenol $)$.

The molecules of DPPH, TEMPOL and DMPO were simulated and studied in gas-phase. In a second step DPPH and TEMPOL were simulated in reduced form with the hydrogen atom incorporated (DPPH-H and TEMPOL-H) and DMPO was simulated with the hydroxyl radical incorporated (DMPO-OH•) and then with a hydrogen atom added (DMPO-OH-H). The phenol and $p$-aminophenol (Scheme 1) were also simulated as reference and parameter for the efficacy of the method. The calculation of the released energy $(\Delta \mathrm{E})$ with the binding of a hydrogen atom was made through the reaction $\mathrm{Fr} \bullet+\mathrm{H} \bullet \rightarrow \mathrm{Fr}-\mathrm{H}$, in which $\mathrm{Fr}$ is free radical and $\mathrm{H}$ is hydrogen atom, as show in equation 3 ,

$\Delta \mathrm{E}=\mathrm{EFr}-\mathrm{H}-\mathrm{EFr}-\mathrm{EH}$

where EFr-H is energy of free radical in reduced form, EFr is energy of free radical and $\mathrm{EH}$ is ground state energy of hydrogen atom $(-13.6 \mathrm{eV})$. The results are presented in Table 3 .

Table 3. Energies of reactions $\mathrm{Fr} \cdot+\mathrm{H} \cdot \rightarrow \mathrm{Fr}-\mathrm{H}$ and difference to phenol BDE

\begin{tabular}{lccc}
\hline & $\begin{array}{c}\left.\Delta \mathrm{E}(\mathrm{kJ} \mathrm{mol})^{-1}\right) \\
\mathrm{Fr} \bullet+\mathrm{H} \bullet \rightarrow \mathrm{Fr}-\mathrm{H}\end{array}$ & $\begin{array}{c}\text { difference to } \\
\text { phenol BDE } \\
\left(\mathrm{kJ} \mathrm{mol}^{-1}\right)\end{array}$ & $\begin{array}{c}\mathrm{BDE} \\
\left(\mathrm{kJ} \mathrm{mol}^{-1}\right)\end{array}$ \\
\hline $\begin{array}{l}\text { Phenol } \\
p \text {-aminophenol }\end{array}$ & & & 372.3 \\
DPPH & -341.3 & -31.0 & $(\Delta \mathrm{BDE}=-47.2)$ \\
TEMPOL & -261.1 & -111.2 & \\
DMPO-OH & -275.4 & -96.9 & \\
\hline
\end{tabular}

\section{Phenol and p-aminophenol}

Phenol was chosen as reference compound due to its known antioxidant properties and has been widely studied for this purpose. ${ }^{34-36}$ On the other hand, $p$-aminophenol was the second compound chosen due to (a) expressive $\triangle \mathrm{BDE}$ when compared to the BDE of phenol; (b) the easiness of simulation due to the similarity with phenol; and (c) the presence of all the atoms that constitute the studied free radicals.

The results of BDE calculations of the phenol indicated $372.3 \mathrm{~kJ} \mathrm{~mol}^{-1}$, and $-47.2 \mathrm{~kJ} \mathrm{~mol}^{-1}$ (Table 3) for $\triangle \mathrm{BDE}$ of $p$-aminophenol, which are in good agreement with the ones reported by other authors. ${ }^{34-38}$ The molecular structure obtained for $p$-aminophenol has $114.3^{\circ}$ for the $\mathrm{H}-\mathrm{N}-\mathrm{H}$ angle and $118.0^{\circ}$ in the respective radical. The increase in this angle when compared to the value of $107^{\circ}$ by $\mathrm{NH}_{3}$ molecule indicates the action of the electron clouds from the aromatic ring approaching a planar structure. These results are in agreement with the expected chemical behavior and used to ascertain the reliability of the calculation method employed.

\section{DPPH and DPPH-H}

The rearrangement of the DPPH molecule being reduced to its respective hydrazine DPPH-H by linking a hydrogen atom to the central nitrogen atom, does not produce significant alterations, keeping the same structure of rings around central atoms and practically unchanged interatomic distances. The optimal structure of DPPH-H is represented in Figure 2. 


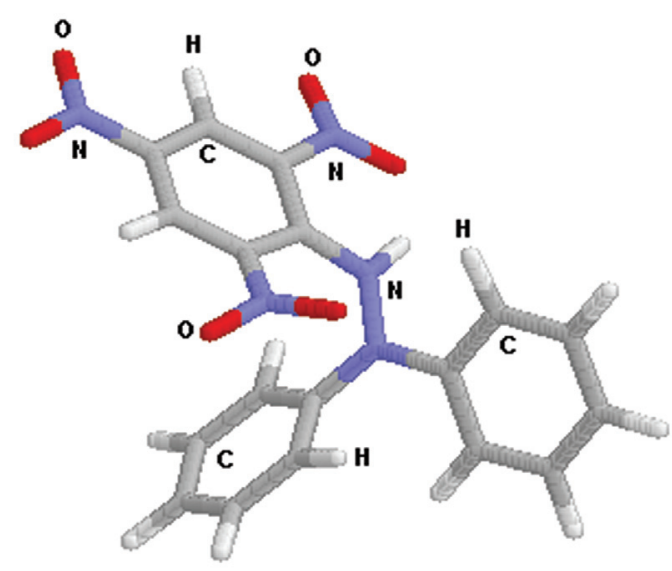

Figure 2. Optimized structure of DPPH-H obtained from computational calculations.

The energy released in the reduction reaction was $-341.3 \mathrm{~kJ} \mathrm{~mol}^{-1}$ indicating the difficulty in reacting with phenol and the relative easiness in reacting with $p$-aminophenol, in accordance with experimental results. ${ }^{39}$ This result indicates that compounds with $\triangle \mathrm{BDE}$ lower than $-31.0 \mathrm{~kJ} \mathrm{~mol}^{-1}$ can also react with DPPH. The low IC 50 (Table 1) of quercetin, flavonoid widely studied, agrees with this conclusion; the $\triangle \mathrm{BDE}$ of quercetin ranges between $-122.5 \mathrm{~kJ} \mathrm{~mol}^{-1}$ and $-19.1 \mathrm{~kJ} \mathrm{~mol}^{-1}$ depending on the hydroxyl analyzed ${ }^{40}$ and reacts quickly with DPPH.

\section{TEMPOL and TEMPOL-H}

The molecular structure of TEMPOL may be depicted in some different forms and in this study five were simulated, changing the ring form from boat to chair and changing $\mathrm{OH}$ and NO positions. The optimal structure obtained with lower total energy is represented in Figure 3. The rearrangement of the TEMPOL molecule being reduced for TEMPOL-H, does not produce significant alterations. One alteration was the change of angles between $\mathrm{C}-\mathrm{N}-\mathrm{O}$, having $115.5^{\circ}$ in TEMPOL and $109.8^{\circ}$ in its reduced form. This change may be due to the $\mathrm{N}$-oxyl radical when producing a displacement in the electronic pairs, while in reduced form it approaches $\mathrm{NH}_{3}$ form. Another important result is the small change in the value of electric dipole, varying from 2.471 D in TEMPOL to 2.442 D in TEMPOL-H. This result indicates the possibility of the same affinity by HBA solvent, for TEMPOL and its respective hydroxylamine reduced, indicating the preferential HAT reaction pathway. Maybe this little difference is linked to the small dependence of rate constant with $\mathrm{pH}$ variations described by Aliaga et al..$^{14}$

The energy released in the reduction reaction of TEMPOL is $-261.1 \mathrm{~kJ} \mathrm{~mol}^{-1}$ (Table 3 ) indicating a greater difficulty in reacting with antioxidant compounds than
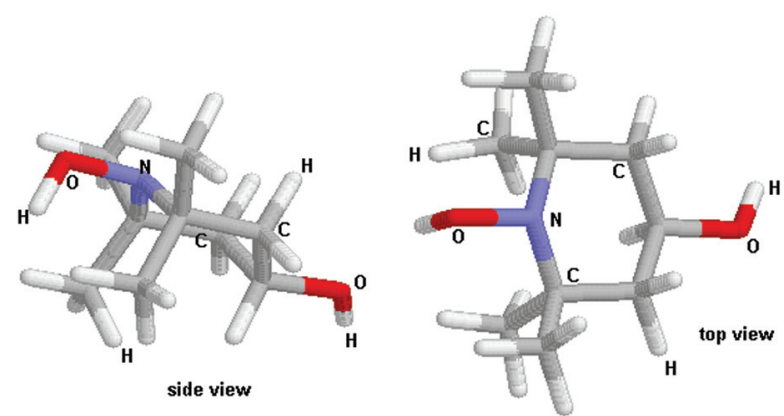

Figure 3. Side view and top view of structural formula of TEMPOL-H obtained from computational calculations.

the DPPH and agrees to its little use for this purpose. Antioxidant compounds with $\triangle \mathrm{BDE}$ lower than $-111.2 \mathrm{~kJ}$ $\mathrm{mol}^{-1}$ can react with TEMPOL considering only the thermodynamic point of view. This value demonstrates that the study of antioxidant properties must be a different form than the DPPH scavenging test, expressing data by the use of an index different from IC 50 or in longer times. Despite these problems, the use of a different test assists a better study of antioxidant properties, especially with other solvents. In this study, the TEMPOL scavenging test was carried out in $24 \mathrm{~h}$ with higher concentrations of extracts and showed some different results than the DPPH scavenging test.

\section{DMPO, DMPO-OH and DMPO-OH-H}

In this study, the spin-adduct formation (DMPO-OH•) and its neutralization for incorporation of the hydrogen atom in the structure was simulated. For the adduct formation, the energy released in the reaction is $-342.1 \mathrm{~kJ} \mathrm{~mol}^{-1}$ as calculated from reaction DMPO $+\mathrm{OH} \bullet \rightarrow$ DMPO-OH $\bullet$. Villamena et al. ${ }^{41}$ reported this value using B3LYP/6$31+\mathrm{G}(\mathrm{d}, \mathrm{p}) / / \mathrm{B} 3 \mathrm{LYP} / 6-31+\mathrm{G}(\mathrm{d})$ level as $-306.0 \mathrm{~kJ} \mathrm{~mol}^{-1}$, and this difference may be due to an underestimation of the N-oxyl energy for the B3LYP method, according to the authors.

The energy released in adduct neutralization was determined as $-275.4 \mathrm{~kJ} \mathrm{~mol}^{-1}$ (Table 3), such value indicates the necessity of $\triangle \mathrm{BDE}$ being lower than $-96.9 \mathrm{~kJ} \mathrm{~mol}^{-1}$ so that one compound reacts to DMPO$\mathrm{OH}$. Despite this higher value, it indicates higher reactivity than TEMPOL and lower than DPPH in agreement with calculated antioxidant activities. The reaction of adduct neutralization with water formation (DMPO-OH・ $+\mathrm{H} \bullet$ $\rightarrow \mathrm{DMPO}+\mathrm{H}_{2} \mathrm{O}$ ) has also been tested; however the result of $-188.9 \mathrm{~kJ} \mathrm{~mol}^{-1}$ indicated that this way is less favorable.

The variation of bond lengths and angles are indicated in Table 4, obtained from optimized structures of DMPO, DMPO-OH and DMPO-OH-H (Figure 4). The increase of 
bond length of C2-N from $1.309 \AA$ in DMPO to $1.478 \AA$ in $\mathrm{DMPO}-\mathrm{OH}$ is in agreement with the change from double to single bond. Another change is the decrease of $\mathrm{N}$ bond angles, which are close to the planar structure in DMPO and close to the pyramidal $\mathrm{NH}_{3}$ structure in the DMPO-OH-H. These results are in agreement with previous results ${ }^{41}$ and again show the reliability of the method.

Table 4. DMPO calculated bond lengths and angles

\begin{tabular}{lcccc}
\hline & Bond & DMPO & DMPO-OH & DMPO-OH-H \\
\hline & $\mathrm{C} 1-\mathrm{N}$ & 1.514 & 1.484 & 1.491 \\
& $\mathrm{C} 2-\mathrm{N}$ & 1.309 & 1.478 & 1.447 \\
Calculated & $\mathrm{O} 1-\mathrm{N}$ & 1.258 & 1.279 & 1.424 \\
bond & $\mathrm{O} 2-\mathrm{H} 2$ & & 1.002 & 0.985 \\
lengths $(\AA ̊)$ & $\mathrm{O} 2-\mathrm{C} 2$ & & 1.381 & 1.399 \\
& $\mathrm{O} 1-\mathrm{H} 2$ & & 1.825 & 2.050 \\
& $\mathrm{O} 1-\mathrm{H} 1$ & & & 0.975 \\
\hline \multirow{5}{*}{ Calculated } & $\mathrm{C} 1-\mathrm{N}-\mathrm{C} 2$ & 111.5 & 112.7 & 108.2 \\
angles & $\mathrm{C} 1-\mathrm{N}-\mathrm{O} 1$ & 118.7 & 120.8 & 110.6 \\
(degrees) & $\mathrm{C} 2-\mathrm{N}-\mathrm{O} 1$ & 129.6 & 115.7 & 107.0 \\
& $\mathrm{~N}-\mathrm{C} 2-\mathrm{O} 2$ & & 107.1 & 112.2 \\
& $\mathrm{C} 2-\mathrm{O} 2-\mathrm{H} 2$ & & 101.9 & 104.2 \\
& $\mathrm{~N}-\mathrm{O} 1-\mathrm{H} 1$ & & & 103.7 \\
\hline
\end{tabular}
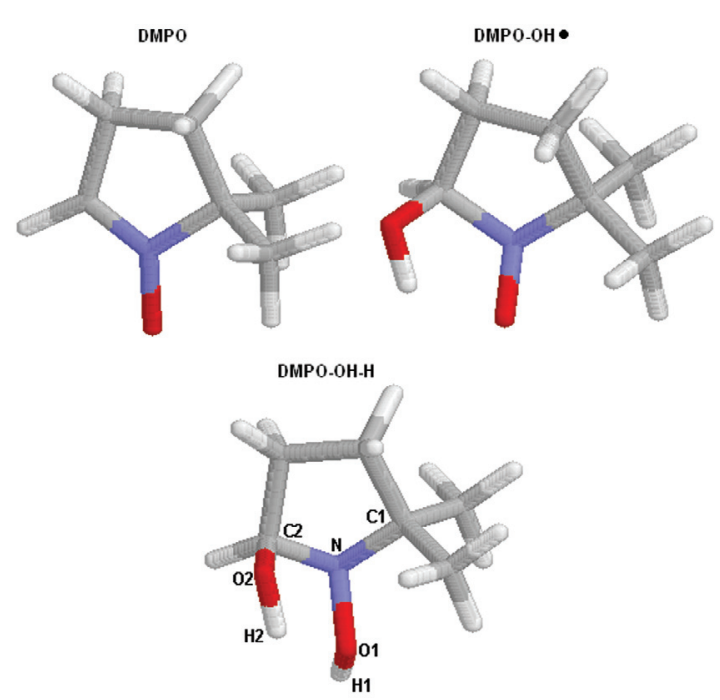

Figure 4. Structural formula of DMPO, DMPO-OH and DMPO-OH-H obtained from computational calculations.

\section{Conclusions}

Ten plant extract samples from Brazilian flora were tested, in three different assays. All the extracts tested displayed significant antioxidant activity in at least one test. The extracts from Iryanthera juruensis (leaf and seed) presented the best results in DPPH and DMPO tests, while the Chrysophyllum inornatum extract was the best in TEMPOL test. The TEMPOL scavenging test, despite the longer time of reaction, may indicate new antioxidant properties, mainly in water solution; and the differences in results indicate the importance of several tests and new studies for understanding the specificity of each test. The differences between released energy of reduction reaction, obtained in computational calculations indicated that TEMPOL is less reactive than DPPH and justified its restricted use. EPR spectroscopy technique proved to be an efficient and fast method for the comparative antioxidant activities, aiding in the selection of the most promising samples. Therefore, it is evident that similar studies are important in the case of a great variety of species such as for screening potential useful plants in bioprospection programs.

\section{Acknowledgments}

The Brazilian agencies FAPESP, CAPES and CNPq for partial financial support; Carlos Brunello and Lourenço Rocha for technical support and to Angela Kinoshita for discussion about this work.

\section{References}

1. Rice-Evans, C. A.; Miller, N. J.; Paganga, G.; Free Radical Biol. Med. 1996, 20, 933.

2. Calliste, C.; Trouillas, P.; Allais, D.; Simon, A.; Duroux, J.; J. Agric. Food Chem. 2001, 49, 3321.

3. Trouillas, P.; Calliste, C.; Allais, D.; Simon, A.; Marfak, A.; Delage, C.; Duroux, J.; Food Chem. 2003, 80, 399.

4. McPhail, D.; Hartley, R. C.; Gardner, P. T.; Duthie, G. G.; J. Agric. Food Chem. 2003, 51, 1684.

5. Polovka, M.; Brezová, V.; Staško, A.; Biophys. Chem. 2003, 106, 39.

6. Amarowicz, R.; Pegg, R. B.; Rahimi-Moghaddam, P.; Barl, B.; Weil, J. A.; Food Chem. 2004, 84, 551.

7. Kinoshita, A.; Franca, A. M.; Almeida, J. A. C.; Figueiredo, A. M.; Nicolucci, P.; Graeff, C. F. O.; Baffa, O.; Appl. Radiat. Isot. 2005, 62, 225.

8. Santos, A. B.; Rossi, A. M.; Baffa, O.; Appl. Radiat. Isot. 2005, $62,213$.

9. Yordanov, N. D.; Christova, A. G.; Fresenius J. Anal. Chem. 1997, 358, 610.

10. Yordanov, N. D.; Ranguelova, K.; Spectrochim. Acta Part A 2000, 56, 373.

11. Yen, G.; Chen, H.; J. Agric. Food Chem. 1995, 43, 27.

12. Valavanidis, A.; Nisiotou, C.; Papageorgiou, Y.; Kremli, I.; Satravelas, N.; Zinieris, N.; Zygalaki, H.; J. Agric. Food Chem. 2004, 52, 2358.

13. Brezová, V.; Polovka, M.; Staško, A.; Spectrochim. Acta Part A 2002, 58, 1279. 
14. Aliaga, C.; Lissi, E. A.; Augusto, O.; Linares, E.; Free Radical Res. 2003, 37, 225.

15. Kocherginsky, N. M.; Kostetski, Y. Y.; Smirnov, A. I.; J. Agric. Food Chem. 2005, 53, 1052.

16. Samuni, A.; Goldstein, S.; Russo, A.; Mitchell, J. B.; Krishna, M. C.; Neta, P.; J. Am. Chem. Soc. 2002, 124, 8719.

17. Finkelstein, E.; Rosen, G. M.; Rauckman, E. J.; Arch. Biochem. Biophys. 1980, 200, 1.

18. Figueiredo, M. S.; Baffa, O.; Neto, J. B.; Zago, M. A.; Res. Exp. Med. 1993, 193, 27.

19. Kohn, W.; Sham, L. J.; Phys. Rev. 1965, 140, A1133.

20. Litwinienko, G.; Ingold, K. U.; Acc. Chem. Res. 2007, 40, 222.

21. Troullier, N.; Martins, J. L.; Phys. Rev. B 1991, 43, 1993.

22. Ordejón, P.; Artacho, E.; Soler, J. M.; Phys. Rev. B 1996, 53, 441.

23. Ceperley, D. M.; Alder, B. J.; Phys. Rev. Lett. 1980, 45, 566.

24. Perdew, J. P.; Zunger, A.; Phys. Rev. B 1981, 23, 5048.

25. Silva, D. H. S.; Zhang Y; Santos, L. A.; Bolzani, V. S.; Nair, M.; J. Agric. Food Chem. 2007, 55, 2569.

26. Fernandes, D. C.; Regasini, L. O.; Vellosa, J. C. R.; Bolzani, V. S.; Oliveira, O. M. M. F.; Silva, D. H. S.; Chem. Pharm. Bull. 2008, 56, 723.

27. Silva, D. H. S.; Pereira, F. C.; Zanoni, M. V. B.; Yoshida, M.; Phytochemistry 2001, 57, 437.

28. Marqui, S. R.; Lemos, R.; Santos, L. Á.; Castro-Gamboa, I.; Cavalheiro, A.; Bolzani, V. S.; Silva, D. H. S.; Scorzoni, L.; Giannini, M. J. S.; Young, M. C.; Torres, L. M.; Quim. Nova, 2008, 31,828 .
29. Magalhães, A. F.; Tozzi, A. M. G. D.; Santos, C. C; Magalhães, E. G.; J. Nat. Prod. 2005, 68, 1290.

30. Burkitt, M. J.; Free Radical Res.Commun. 1993, 18, 43.

31. Li, L.; Abe, Y.; Kanagawa, K.; Usui, N.; Imai, K.; Mashino, T.; Mochizuki, M.; Miyata, N.; Anal. Chim. Acta 2004, 512, 121.

32. Matthäus, B.; J. Agric. Food Chem. 2002, 50, 3444.

33. Jovanovic, S. V.; Steenken, S.; Tosic, M.; Marjanovic, B.; Simic, M. G.; J. Am. Chem. Soc. 1994, 116, 4846.

34. Lucarini, M.; Mugnaini, V.; Pedulli, G. F.; Guerra, M.; J. Am. Chem. Soc. 2003, 125, 8318.

35. Brinck, T., Haeberlein, M., Jonsson, M.; J. Am. Chem. Soc. 1997, 119, 4239.

36. Lithoxoidou, A. T.; Bakalbassis E. G.; J. Phys. Chem. A 2005 , 109, 366

37. Lucarini, M.; Pedrielli, P.; Pedulli, G. F.; Cabiddu, S.; Fattuoni, C.; J. Org. Chem. 1996, 61, 9259.

38. Lind, J.; Shen, X.; Eriksen, T. E.; Merényi, G.; J. Am. Chem. Soc. 1990, 112, 479.

39. Brand-Williams, W.; Cuvelier, M. E.; Berset, C.; Food Sci. Technol. 1995, 28, 25.

40. Trouillas, P; Marsal, P.; Siri, D.; Lazzaroni, R.; Duroux, J.; Food Chem. 2004, 97, 679.

41. Villamena, F. A.; Merle, J. K.; Hadad, C. M.; Zweier, J. L.; J. Phys. Chem. A 2005, 109, 6083.

Received: August 08, 2008

Web Release Date: August 28, 2009

FAPESP helped in meeting the publication costs of this article. 